\title{
Change of Ovarian Function with Age
}

\author{
Seiichi MATSUMOTO \\ Department of Obstetrics and Gynecology, Gunma University \\ Medical School, Maebashi, Japan
}

It is recognized statistically and clinically that the lowering of female fertility appears with age. During the climacteric, there is frequent to happen ovarian dysfunction, such as menstrual disorders or dysfunctional uterine bleeding, and the climacteric symptoms as somatic and psychic changes. These clinical changes suggest the lowering of ovarian function according to aging. However, from the aspects of urinary estrogen level, the strinkig decrease of the level is not observed before menopause. In postmenopausal women, it is low value, as general, but the higher levels are revealed in some cases. In any event, very low level as in childhood is not observed.

From the recording of 18, 213 menstrual cycles, it is observed that the length of cycle shortens with age. Basal temperature records of 3,000 ovulatory cycles shows that the average length of follicular phase shortens with age, although that of luteal phase does not change in women of over 20 years old. So it is clear that the shortening of menstrual cycle is a result of shortening of follicular phase. The shortening of period and decrease of flow are also observed in women of over 35 years old, and the increase of inadequate luteal phase or anovulatory cycle especially in women of over 40 years old.

Lowering of ovarian function with age does not mean only the decrease of estrogen secretion, but irregularity of ovarian cycle function that induces umblance of estrogen and progesterone secretion. The fact that the endometrial hyperplasia induced by prolonged or profuse estrogen action frequently takes place in climacteric women supports the abovementioned opinion.

Urinary total gonadotrophins increase in some cases of menopausal women, and rise remarkably in postmenopausal women. Follicle stimulating hormone is within normal value or a little higher before menopause, and rises usually in postmenopausal women. Then, in more than five years after menopause, FSH tends to return to normal range. $\mathrm{LH}$ increases to ovulatory level in postmenopausal women. Urinary $17 \mathrm{KS}$ value increases during menopause.

With age, ovarian size becomes smaller, and following histological changes appear: appearance of germinal inclusion cyst or corpus albicans cyst, disappearance of corpus luteum, decrease of atretic follicle, disappearance of graafian follicle, decrease of a number of a internal theca cell and interstitial cell, accumulation of Sudan IV strain in ovarian cortex, and increase of Sudan IV strain in wand of ovarian vessels. From these phenomenon, 
it is supposed that structual ovarian atrophy begins between 35 and 40 years old. Especially blood vessels in ovary change remarkably after 35 years old. So, the change of ovarian vessel is suggested to play an important role to lowering of ovarian function.

(See pp. 715 720) 


\title{
Aging \& Sexagen :-Dynamic Study of Exogenous Progesterone in Aging, Castrated, and Normal Adult Women
}

\author{
Haruo ADAGHI, S. MIZUTANI, I. KUROBE, \\ H. TAKAHASHI and T. OZASA \\ Department of Obstetrics and Gynecology, School of Medicine, \\ Tokushima University, Tokushima, Japan
}

To investigate the change of human ovaries with age, the author studied the patterns of steroid excretion in the urine after parenteral administration of 20 to $50 \mathrm{mg}$ of progesterone to women of reproductive age, those after menopause and castrated by oophorectomy.

The following methods as modified by Kambegawa were used: Klopper's method for pregnanediol, Detector's method for total 17-ketosteroids, Glenn and Nelson's method for 17-hydroxycorticosteroid, Brown's method for estrogens and Kambegawa's method for pregnanetriol.

1) Women of reproductive age in either the follicular or luteal phase showed no definite change in pregnanediol excretion in the urine immediately after administration of progesterone. However, subsequently excretion gradually increased for 3 days reaching $150 \%$ of the initial level in those in the follicular phase. In women after menopause the amount increased to $2450 \%$ of the initial level after progesterone administration, being far more than in the follicular phase in women of reproductive age, while in castrated women, it increased to $200 \%$ within 24 hours after progesterone administration.

These results show that metabolism of exogenous progesterone and the pattern of excretion of pregnanediol differ depending on whether ovarian function decreases gradually, as in menopause, or whether it ceases abruptly, as after castration.

2) The excretion of pregnanetriol in the urine increased in postmenopause women to $130 \%$ of the initial level 48 hours after administration of progesterone, while it decreased in both reproductive and castrated women.

3) The excretion of total 17-ketosteroids gradually increased after administration of progesterone, in women of reproductive age in the follicular phase but there was no definite change in women in the luteal phase, or in women after menopause or castration.

4) Excretion of 17-hydroxycorticosteroids after progesterone administration to women in the luteal phase increased slightly and increase after 2 days in postmenopause women. But in castrated women it increased to $130 \% 24$ hours after progesterone administration and no tendency of increase was recognized thereafter.

5) Excretion of total estrogens in the urine after administration of progesterone increased in women in the follicular phase. In the luteal phase it increased to $145 \%$ within 
24 hours and then decreased slightly. In castrated women, it increase to $130 \%$ within 24 hours, while in women after menopause, it increased slowly and gradually to $270 \%$ on the third day after progesterone administration, a higher level than in the follicular phase. These results show that the metabolism of, or physical reaction to exogenous progesterone varies depending on whether women are in the postmenopause stage or whether they are castrated.

(See pp. 721 722) 


\section{シンポジゥムI 加令と内分泌 \\ 3. 加令による卵巣機能の変化}

群馬大学産婦人科

松本 清 一

\section{1. 加令による妊孕力の低下}

女性の妊孕力は加令によつて低下する。昭和 40 年の人口動態統計から有配偶女子 1,000名が何人の子供を 産んだかを年令階級別に計算してみると，15〜19才約240名，20２4才350名，25２9才 250 名，30〜34才 100 名，35〜394才 20 名，40〜44才 3 名，45〜49才0.2名となり，20才代前半が最高で，30才からは著減している. もつとも近年は受胎調節や人工娃娠中絶の影響を考えないわけにゆかないので自然の妊学力の推移がての通 りであるとはいえない，そてで受胎調節などが殆ど問題にならなかつた戦前の統計を昭和15年度日本婦人科 学会地方部会調查成績の報告 ${ }^{4)}$ から引用してみた。乙れには大正14年, 昭和 5 年, 昭和 12 年の統計によって 16〜27才の有配偶女子の出生率が各年令別示されているが，大正 14年には 21 才がピークで有配偶女子 1,000 名対 358 名, 昭和 5 年には20才がピークで 355 名, 昭和 12 年には 21 斿ピークで 334 名であり, ぞの年度 も大体20〜22才頃をピークとして以後出率は減少している.

このような加令による妊冧力の低下, 特に35才以上での著減は臨床的にも認められるし, 妊娠中や分婏時 の異常も増し，妊産娠死亡率が著増するととも認められている。

また更年期になれば月経周期異常, 機能性子宮出血などの卵巣機能障害や全身的な所謂更年期症状が頻発 する，てのような臨床的事実は加令によつて卵巣機能の低下を推定させる.

\section{2. 尿中 estrogen 量の推移}

西田 $\left.(1969)^{6}\right)^{6}$ が報告した尿中 estrogen 量の年令による推移をみると，その平均值には20才代をピークと して幾分低下の傾向がみられるものの，個々の值でみれば，50才台位までそう著明な低下は認められない。 教室の飯島, 石川が Brown の新迅速法 ${ }^{2}$ 亿よつて閉経前後の婦人の尿中 estrogen 量を測定した結果は図 1 に示すようで，その值は閉経前はあまり減少していない，閉経後は低值の例が多いが，中には高值を示す例 もある. 成熟期の婦人の尿中 estrogen 量は月経周期の間に著明な変動を示し，例えば卵胞期の初期と排卵 期や黄体開花期とでは相当値に違いがあるから，周期の時期を考慮に入れなければ正常値の巾はきわめて広

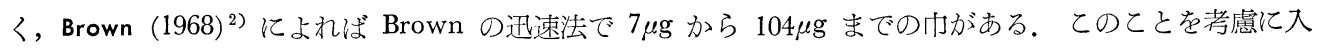
れれば閉経前の值は正常範囲内での変動であり, 閉経後の值も小児期のような低值にはならない。

\section{3. 月経周期日数の変化}

正確な記録によつて得られた701名の18.213 周期について月経周期日数を調べ年令階級別にその累積度数 分布をみると図 2 に示すようで年令の進むにつれて次第に周期日数か短い方へ傾よるてとが判る.また質 問による13.380周期での調查，月経記録による18.213周期での調查わよび基礎体温記録による正常排卵周期 3,000周期での調查によつて調べた月経周期日数の統計からそれぞれ分布の中央 $80 \%$ が存在する範用を年令 階級別に見るとその範囲はどの方法でみても年令が進むに従つて周期日数の短い方に移行している.

基礎体温によつて排卵性周期であるてとが明かな 3,000 周期について，月経周期日数，低温相すなわち卵 
Fig. 1. Urinary estrogen levels in women before and after menopause
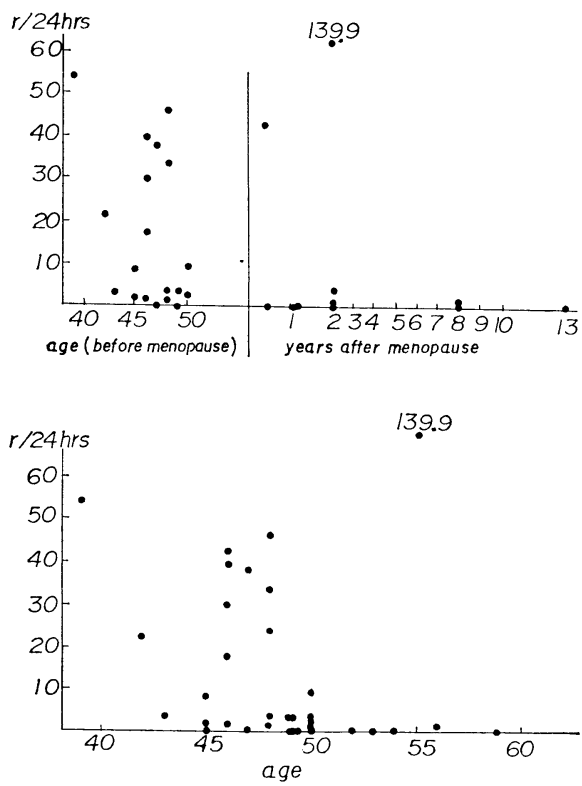

Fig. 2. Cumulative distribution of the cycle length among age groups

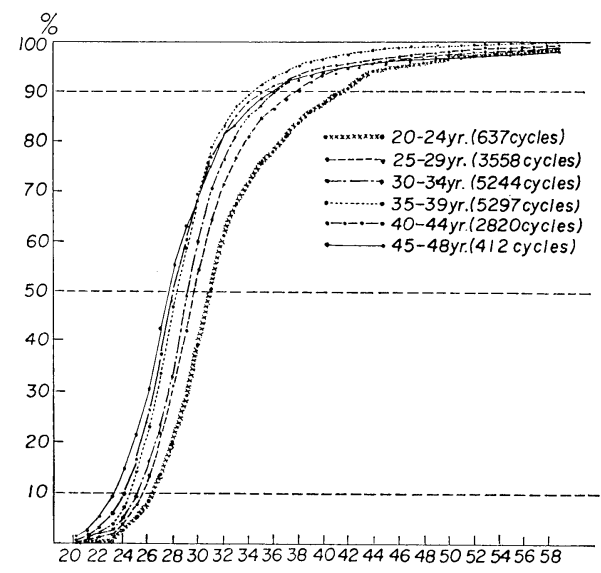

胞期の日数および高温相すなわち黄体の日数の分布 を年令階級別にみると高温相日数は10才代では明ら かに短いものが多く，また40才以上でもそれがやや 増しているが，20才から39才の間ではその分布に殆 ぞ差がみられない，乙れに反し低温相日数は年令の

進むと共に漸次15日以下のものが増して，21日以上の長いものが減少しているし，表 2 にそれぞれの平均值 と標準偏差とを示したが，てれをみても段々に短くなつているととが判る。このととから周期日数の短縮は 卵胞期の短縮によつて起ることが明かであるし，また40才以上では排卵性の周期でも黄体機能不全の傾向を 有するものの多いてとが推定される.

\section{4.月経持続日数と経血量の変化}

基礎体温によつて確認した正常排卵周期 3,000 周期の月経持続日数の分布を年令階級別にみると35才以後

Table 1 Age difference in the length of menstrual cycles, follicular phase and luteal phase

\begin{tabular}{|c|c|c|c|c|c|c|c|}
\hline \multirow{2}{*}{ Age } & \multirow{2}{*}{$\begin{array}{l}\text { No. of } \\
\text { cycler }\end{array}$} & \multicolumn{2}{|c|}{ Length of cycles in days } & \multicolumn{2}{|c|}{$\begin{array}{l}\text { Length of follicular } \\
\text { phase in days }\end{array}$} & \multicolumn{2}{|c|}{$\begin{array}{l}\text { Length of luteral } \\
\text { phase in days }\end{array}$} \\
\hline & & Average & S.D. & Average & S.D. & Average & S.D. \\
\hline $13-17$ & 280 & 34.67 & 9.43 & 22.97 & 9.39 & 11.72 & 1.54 \\
\hline $18-19$ & 100 & 33.16 & 6.62 & 20.99 & 7.07 & 12.20 & 1.89 \\
\hline $20-24$ & 350 & 31.00 & 5.67 & 18.41 & 5.65 & 12.39 & 1.56 \\
\hline $25-29$ & 1000 & 31.38 & 7.46 & 18.58 & 7.43 & 12.66 & 1.63 \\
\hline $30-34$ & 750 & 30.07 & 5.51 & 17.23 & 5.31 & 12.76 & 1.64 \\
\hline $35-39$ & 400 & 29.40 & 4.80 & 16.71 & 4.54 & 12.63 & 1.62 \\
\hline $40-52$ & 120 & 28.37 & 4.02 & 15.91 & 4.28 & 12.46 & 1.76 \\
\hline Total & 3000 & 30.96 & 6.75 & 18.36 & 6.75 & 12.54 & 1.66 \\
\hline $20-39$ & 2500 & 30.57 & 6.36 & 17.85 & 6.24 & 12.65 & 1.63 \\
\hline
\end{tabular}


Table 2. Size of orary by age

\begin{tabular}{c|c|c}
\hline \hline Age & No. of cases & Size of ovary (Average c.m.) \\
\hline \hline $5-9$ & 1 & $0.8 \times 0.6 \times 0.5$ \\
$10-14$ & 1 & $3.6 \times 0.8 \times 0.5$ \\
$15-19$ & 2 & $4.0 \times 2.8 \times 1.4$ \\
$20--24$ & 6 & $4.3 \times 2.8 \times 1.6$ \\
$25-29$ & 5 & $4.0 \times 3.4 \times 1.9$ \\
$30-34$ & 14 & $3.2 \times 2.1 \times 1.5$ \\
$35-39$ & 22 & $3.0 \times 2.2 \times 1.4$ \\
$40-44$ & 38 & $3.0 \times 2.1 \times 1.2$ \\
$45-49$ & 26 & $3.1 \times 2.0 \times 1.2$ \\
$50-54$ & 19 & $2.7 \times 1.5 \times 1.0$ \\
$55-59$ & 14 & $2.7 \times 1.4 \times 0.9$ \\
$60-64$ & 8 & $2.4 \times 1.2 \times 0.8$ \\
$65-69$ & 9 & $2.3 \times 1.1 \times 0.7$ \\
$70-74$ & 2 & $1.3 \times 0.9 \times 0.8$ \\
$75-79$ & 1 & $2.5 \times 1.5 \times 1.0$ \\
$80-$ & 3 & $1.4 \times 0.7 \times 0.5$ \\
\hline Total cases & 171 & \\
\hline
\end{tabular}

では明かに短い方に傾つている，また経血量は一定の基準による質問で，経血量を 4 段階に分けて指数とし て表現し，月経期間中毎日それを記載させた，2,012名についての調查結果によると，指数 4 。すなわち多 量の日があるものは 35 才以上になると減じ，全経過中指数 2 以下，すなわち少なめの者が35才以上になると 増している，従つて経血量は35才以上になると減少すると考光られる．教室の野上 $(1966)^{7}$ が $\mathrm{Cr}_{51}$ を用い て月経中に失われる血液量を算定した結果でも経血量が中等量といつている $21 〜 24$ オの 3 例では $57 \sim 117 \mathrm{ml}$

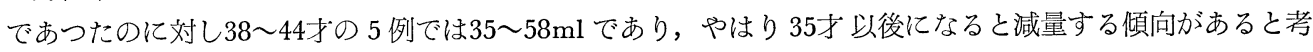
えられた。

\section{5. 閉経前の月経周期}

前述した月経周期日数の分析で40才以上では排卵性の周期でも高温相の短い周期が多くなるととを認めた が，35才以上の婦人について基礎体温の所見から，月経周期を正常の排卵性周期，黄体機能不全周期及び無 排卵性周期の 3 者に分け，それぞれの頻度を見た結 果図 3 亿示すようである。黄体機能不全周期とし ては 2 相性の周期のうち, 高温相日数が 9 日以下の もの, 低温相と高温相の温度差が 3 分以下のもの, および私共のV型に属するものをとつた．この結果 をみると，45才頃から正常の排卵性周期か減つて無 排卵性周期が増し，特に50才以後でそれが著明であ る.また閉経まで基礎体温が記録されていた10名の 婦人の閉経前周期 201 周期について月経周期を同様 亿分類してみると図 4 のようで, 閉経前 2 年前頃 から漸次排卵性周期が成り，無排卵性周期や黄体機 能不全周期が増している。閉経前何周期目かれよつ

Fig. 3. Relation between age and types of ovarian cycles determined by BBT

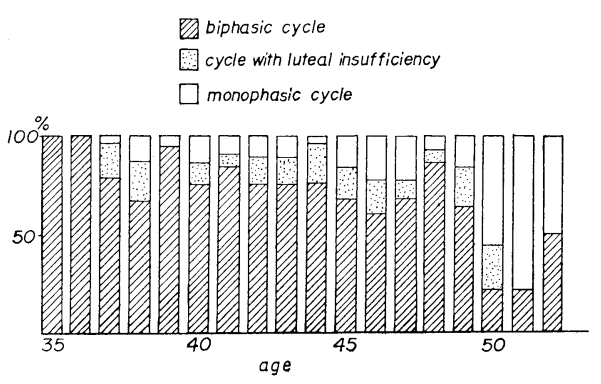


Fig. 4. Types of ovarian cycles determined by BBT before menopause
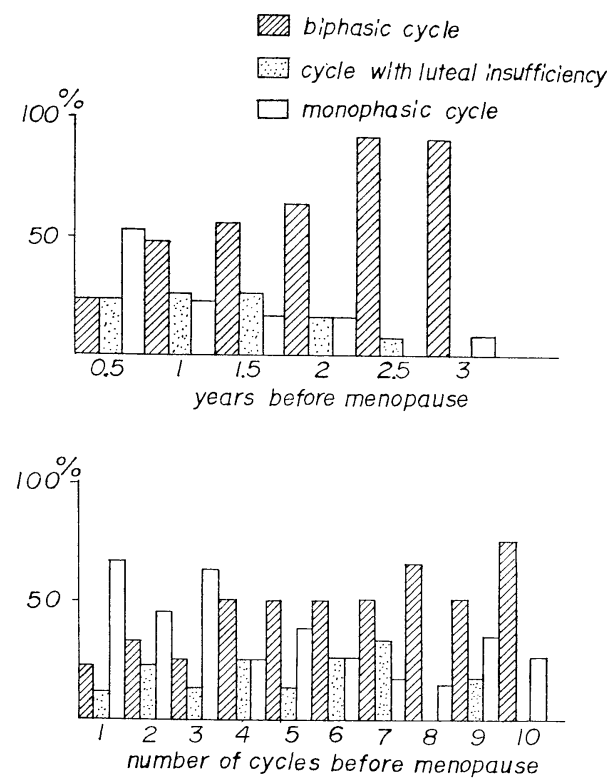

Fig. 5. Variation of length of menstrual cycle before menopause
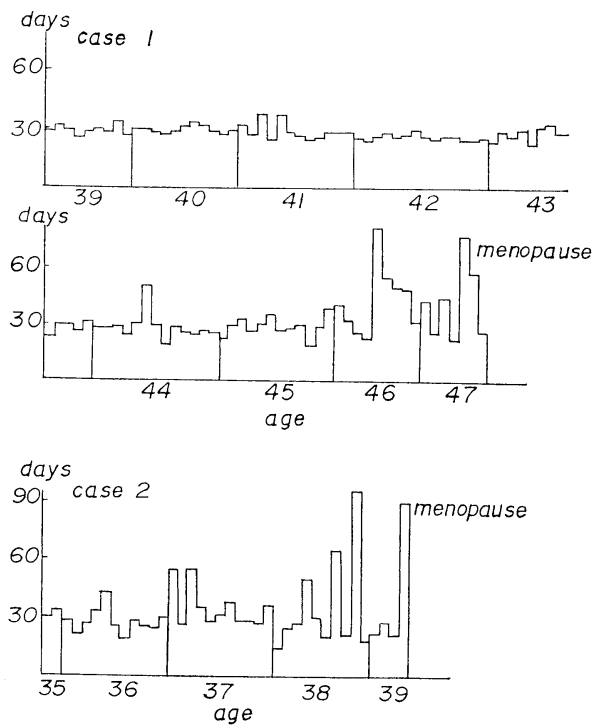

て分けてみてもやはり閉経に近づく程無排卵性周期が増し特に閉経前の 3 周期は過半が無排卵周期であるて とが認められる。しのような無排卵周期や黄体機能不全の周期が増加するのに伴つて月経周期日数は変動が 強くなり，周期の不正が著明になる．図 5 は代表的な 2 例について閉経前の月経周期日数の変化を図示した もので，ての 2 例では閉経の凡そ 1 年半前位から周期の不正が著明になつている。また中には閉経の 3 年も 前から不正が明かになつている例もある。

\section{6. 加令による卵巣機能低下}

以上から月経周期については，加令に伴つて，排卵周期では畍胞期の短縮による月経周期日数の短縮が認 められ，35才以上になると月経持続日数が短縮し，経血量が減少するととや，また閉経に近づくと黄体機能 不全周期や無排卵性周期が增すととが認められた。このととから加令による卵巣機能低下は単なる estrogen 分泌の低下というととではなく，卵雀周期性機能の不正化と，それに伴う estrogen と progesterone との 不均衡が特幑であるといえる。すなわち黄体機能不全周期では progesterone の作用は減るし，無排卵性周 期では黄体期を欠くから estrogen の作用が長く持続するととになる。卵巣機能が減退したはずの更年期に しばしば estrogen の過剩作用に基づく子宮内膜過増殖症が起てり，それによつて機能性子宮出血が招来さ れるととは一見矛盾を感しさせるが，乙のととは上述のような発生機序によつて説明される。

\section{7. 尿中 gonadotrophin の推移}

Albert (1956) 1) によれば，尿中の total gonadotrophin は閉経前から徐々に增加の傾向を示し閉経後は さらに急增して閉経後15乃至19年後にピークを示し，その後は再び漸減すると報告されている．教室の五十 嵐 $(1967)^{3}$ )が閉経前後の婦人について尿中 gonadotrophin を FSH と LH とに分け，FSH を五十嵐一 McCann 法で，LH を卵栄アスコルピン酸減少法の横田変法で測定した結果は図6に示すようで，FSH は閉経前は正常範囲かまたはやや高值を示している。1例40才ですでに異常高值を示しているが，乙の例は 更年期障害を訴えていて既に閉経の近いととが予想された例である.閉経後は 1 ケ月ですでに異常高值を示 
Fig. 6. Urinary hormone levels in climacteric women

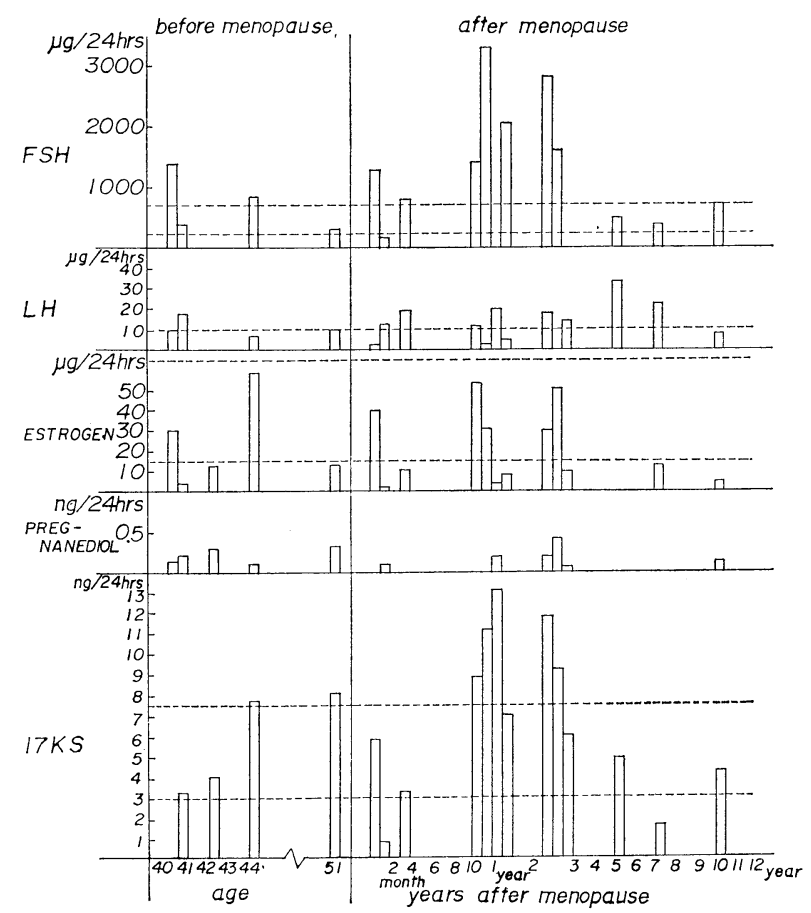

し，10ケ月から 3 年にかけて更に上昇して $2,000 \mu \mathrm{g} \sim 3,000 \mu \mathrm{g}$ NIH-FSH-Eg の高値に達するが， 5 年以後 は再び減少して正常範囲に戻る傾向が認められる.

一方 LH も閉経前は大体正常值を示すが, 閉経後には性成熟婦人の排卵期に相当する高値を示し, 閉経 後 5 年の 1 例では $33.44 \mu \mathrm{g}$ NIH-LH-Eg の高值がみられた.

同時に測定した尿中 estrogen は前述したのと大体同様の結果で閉経後は概して低值を示すが中には正常 範囲の高值を示す例もある。尿中 $17-\mathrm{KS}$ は閉経後10ケ月から 3 年の間で異常高值を示しており，ての時期 にはFSH も高値を示しているので，乙れは副腎からの androgen 分泌㳰響を及ぼしているのではない かとも考えられる。

\section{8. 尿中 17KS および 17OHCS の推移}

西田 $(1969)^{6)}$ とれれ゙尿中 $17 \mathrm{KS}$ の年令による推移をみると，20才代がピークで，30才代でやや減じ， 以後50才代まではほぼ一定の値を保ち，60才代から急激に減少している。すなわち尿中 $17 \mathrm{KS}$ 值の推移は 卵巣の機能の閉止とは関係なく，その大部分は副謷性 androgen に由来するもので，閉経後10年間位は閉 経前の值を維持し，60才代に至つて激激すると考光られている。 ての副腎性 androgen の分泌か閉経後は 増加するFSH の作用によつて支えられているかどうかは興味あると思われる。

尿中 17OHCS は西田 $(1969)^{6)}$ の報告によれば30才代をピークにして以下漸減するが，60才以後になつ てもその平均值は $20 才$ 代と大体同じ位の值を示しており, このととは生体防衛としての glucorticoids の重 要性を物語るものと考觉られている.

\section{9. 加令による卵巣の形態学的変化}

加令による卵巣の形態学的変化を手術または剖検によつて得た200例の卵巣について教室の高沢8) が調べ 
たが，そのうち大きさを測定し得た171例で大きさの変化をみると表 2 亿示すようで，例数の分布が平均し ていないので，余り明らかなととは言えないが，19才から29才の間が最も大きく，30才以後は縮小し，50才 以後で更に縮小の度が增し，60才以後はそれが更に著明になるようである．てのような大きさの減少の他 に, 加令に伴つて出現する現象として, germinal inclusion cyst および corpus ablicons cyst の出現, 黄体の消失，閉鎖細胞の減少，成熟卵胞の消失，内荻膜細胞および間質腺細胞の減少，卵巣皮質への Sudan IV の蓄積，卵巣血管壁のSudan IV 染色性の増化などが現われることを認めた。乙れらの現象の出現す る年令をみると, germinal inclusion cyst は30才頃から出現して50才から55才の間で最も著明になるし， 黄体は 35 才頃から減り，45才以後更に著減し，成熟卵胞も45才以後減少する。また卵巣皮質への Sudan IV 蓄積は 40 才頃から出現し，50才以後更に明かとなり，55才以後は更に著明になるがこの所見は卵巣老化の指 標として重要と思われる。

てれらの所見を総括すると形態学的には卵巣の老化は 35 才及至 40 才頃から著明になると思われる.

また卵巣血管の内膜と中膜の Sudan IV による染色性を見ると，25才位から次第に血管の変化が現われ 始め，35〜39才頃より変化が著しくなり，45才以後では変化のないものは1例もない. weigert 弾性線維染 色を行う之内膜の肥厚の程度が非常に明膫である．また haematoxilri-eosin 染色による血管の内膜肥厚硝 子化は大体 Sudan IV 染色による変化と一致している. 血管壁の cholesterol test は35〜86才の143名中に 8 名陽性を示し sulfuric acid reaction は40〜86の117名中に9 名陽性を呈した。なおてのような血管の変 化は全身的な血管硬化とは特に関係がないようである，てのように卵巣血管壁の変化が35才以後の卵巣では 著明に認められるととから，てれが泪巣機能の減退に重要な役割りを演じているのではないかとも考えられ る.

\section{0. ま め}

以上から卵巣の退化課程は大体 35 才ないし 40 才頃から起り始め，それに伴つて卵胞期の短縮，更に黄体機 能不全周期や無排卵性周期の出現，増加など，卵巣の周期性機能の変化を招来させると思われる，その結果 estrogen と progesterone との不均衡が生じるが，更に閉経前後からは gonadotrophin の増加， estrogen の減少が起り，それと共偪副腎皮質の代償作用が働き，てれらが全身的に種々の影響を及ぼす。しかし閉経 後 5 年以上乃至 10 年以上経つと gonadotrophin は再び減少して大体正常值に戾り, 副腎由来の androgen も低値になつて安定した老年期に入ると考壳られる

\section{文献}

1) ALBERT, A. (1956) : 五十嵐 (3) より引用

2) BROWN, J.B., MAGLEOD, S.G., MAGNAUGHTAN, G., MSITH, M.A. \& B. SMYTH : A Rapid Method for Estimating Oestrogens in Urine Using a Semi-automatic Extractor. J. Endocr. $42: 5$, (1968)

3）五十嵐正雄：脳下垂体性ゴナド トロピン分泌関する研究。第19回日本産科婦人科学会総会宿題報告要旨, (1967).

: 昭和 15 年度日本婦人科学会地方部会調査成績の総括。日婦会誌 $36: 457,(1941)$.

4) 木下正中 月経とその異常, 医学の世界社, 東京, (1962)

6）西田悦郎：産科婦人科領域に招ける老年医学的 研究, 第21回日本産科婦人科学会総会宿题報告要旨, (1969)

7）野上保治：経血量住関する研究。 日本不妊学会誌 $11: 189$, (1966) 8) TAKAZAWA, K., ITO, T. \& S. MATSUMOTO : Histochemical Study on Aging of Ovary. J. Jap. Obstet. \& Gynec. Soc. 11 : 105, (1964) 


\title{
追加発言
}

\author{
加令と性ホルモン \\ 徳島大学産婦人科 \\ 足立 春雄, 水谷 重康, 黒部 未, 高橋 久寿, 小笹 皓雍
}

aging とはいちがいに定義し難い生理的な現象であるが，既に1955年 Engle は機能を営んでいた実質 性の藏器内に結合織既ち collagen が浸潤する事と疲労からの回復が遅くなる事であると定義しているが, その本体は残念ながら今尚明らかではなく甚だ曖昧なものである. 人の卵巣を例にとれば卵巣では思春期に なれば原始卵胞のあるものは成熟卵胞になり排卵し，またあるものは閉鎖卵胞となつて萎縮退行する．当然 排卵のあとは黄体となりやがてはてれが結合織によつて置換えられ白体を形成するのである．ての事はとり もなおさず少くとも排卵の後が結合織で置換えられる事になり，卵巣では排卵が始まる事はすでに老化が開 始された事を意味する，しかしながら，その後に於いて女性本来の性機能が始まる事となるので奇妙な理論 と現実の相克がみられる．多くの婦人では50才をてえた卵巣は萎縮した線維性臓器となる．てれら老化に伴 う卵栄機能を知る為には多数の学者により性ホルモンの排泄量の年令的な推移を測定して老化と卵巣機能と の関連性を求めたり特に卵巣ホルモンの主体である estrogen の 3 分画の変動を検討したりあるいは性腺刺 激ホルモンの排泄量を測定したりして検討されている。

他方卵巣の estradiol の分泌能力が70才から90才迄存在する事が Pearlman らの報告によつても明らか であるが，ての線維化した卵巣が尚 estrogen を分泌する事を排卵現象にその源を求めるよりも卵巣をもつ 事の為のステロイド代謝の意義も注目されてよからうと考える.

我々は aging による卵巣機能の漸進的衰退と手術による去勢の様な急激なる卵巣機能の廃絶の間にステ ロイド代謝の変動があるか否かを検討中であるのでその一部を追加する。すすなわち progesterone $20 〜 50 \mathrm{mg}$ の排経口的投与後の尿中ステロイドの排泄パターンを開経後婦人, 性成熟婦人, 正常成熟婦人について比較 検討した成績を追加する。

尿中ステロイドの測定法は pregnanediol は Klopper 氏法, total 17-KS は Detector 氏法, 17-OHCS は Glenn \& Nelson 氏法, estrogen は Brown 氏法の各れも神戸川氏変法に, さらに pregnanetriol は 神戸川氏変法に従つて測定した。

(1) Progesterone の主要代謝産物である pregnanediol の排泄パターンをみると正常成熟婦人の卵胞期 と黄体期では投与後の量的な排泄值に差はないが, 黄体期が投与後 3 日目迄漸増し, $150 \%$ 増加するのに対 し, 卵胞期では約 $500 \%$ の增加を示す。一方閉経後婦人では progesterone 投与前に比して，2450\%の増加 を示し，量的に対比しても卵胞期をはるかに上回る排泄を示し，去勢婦人では投与後第 1 日目に $200 \%$ 増加 を示すにすぎなかつた。 ての事から卵巣機能が急激に欠落した去勢婦人と, 自然に機能の欠落した状態にあ る閉経後婦人との間に pregnanediol の排泄パターンの上に大きな違いがある事がわかり, 各対象婦人の体 外性 progesterone 亿対する生体反応の相違をうかがい知る事が出来る.

(2) Pregnanetriol みると成熟期では殆んぞ負の排泄パターンを示したのに反し閉経後婦人で投与後第 2 日目 $130 \%$ 增加を示した他は去勢婦人共負の排泄パターンを認めた。

(3) Total 17-Ketosteroids は卵胞期に漸増傾向を認めたのに対し, 黄体期, 閉経後, 去勢婦人共各無投 与を対象とした control 群の変動に比し差を認めなかつた。

(4) 17-hydroxycorticosteroids をみると total 17-KS とは異なり正常成熟婦人黄体期に増加㑯向を, 閉経後婦人では 2 日目より増加傾向を示したが，去勢婦人では投与後 1 日目 $130 \%$ 増加を示し以後著変を認 めなかつた。 
（5） Total estrogens は正常成熟婦人の卵胞期に軽度増加㑯向を認め黄体期で投与後第 1 日目 $145 \%$ 増加 後娍少㑯向を認める. 去勢婦人では投与後第 1 日目 $130 \%$ 増加を認めた他 control に比して著変なかつたの に反して, 閉経後婦人では漸増傾向をとり, 投与後第 3 日目 $270 \%$ の增加を認め, 卵胞期に対してそれを上 回る排泄を示した. Total estrogens の排泄パターンからも閉経後婦人と去勢婦人との間に体外性 progesterone の生体内での代謝過程に，換言すれば生体反応泪違のある事がうかがわれる. 